九州大学学術情報リポジトリ

Kyushu University Institutional Repository

\title{
THE FAMILY CURCULIONIDAE OF JAPAN. III. SUBFAMILY ANOPLINAE
}

Morimoto, Katsura

Entomological Laboratory, Faculty of Agriculture, Kyushu University

https://doi.org/10.5109/2436

出版情報 : ESAKIA. 20，pp.63-68，1983-12-15. Entomological Laboratory，Faculty of Agriculture， Kyushu University

バージョン :

権利関係 : 


\title{
THE FAMILY CURCULIONIDAE OF JAPAN. III. SUBFAMILY ANOPLINAE*
}

\author{
KATSURA MORIMOTO \\ Entomological Laboratory, Faculty of Agriculture, \\ Kyushu University, Fukuoka 812, Japan
}

\begin{abstract}
This is the third part of the revision of Japanese Curculionidae, treating the Anoplinae, which contain one genus, Anoplus, and two species, plantaris (Naezen) and japonicus sp. nov. Anoplus sugiharai Kôno is newly synonymized with plantaris.
\end{abstract}

The Anoplinae are a small subfamily containing only one genus, Anoplus Schoenherr, and four species, plantaris (Naezen), roboris Suffrian, setulosus Kirsch, and sugiharai Kôno, from the Palaearctic Region. Anoplus sugiharai is newly synonymized with plantaris and japonicus is described as new in this paper.

Before going further I wish to express my cordial thanks to Prof. Y. Hirashima of Kyushu University for his kind guidance in the course of the present study. My thanks are due to Prof. S. Miyamoto, Prof. Y. Murakami, Prof. S. Kimoto, Dr. M. Takahashi, and Mr. I. Matoba for their kindness in giving me the important specimens.

\section{Subfamily Anopinae}

Rostrum rather robust, curved, nearly as long as pronotum. Antennae inserted before the middle of rostrum. Eyes well distant from thorax. Prothorax without ocular lobes ; prosternum shallowly concave, not canaliculate; fore coxae contiguous. Scutellum evident. Elytra with humeri, ten striate. Pygidium covered. Femora edentate; tibiae uncinate. Tarsithreesegmented, claw segment wanting. Metepisterna entire, reaching posteriorly to first ventrite. First ventrite behind coxa as long as second, the latter as long as third and fourth combined. Male aedeagus with penis rather flat, struts about as long as penis, inner sac asperate, without sclerite; tegmen

* Contribution from the Entomological Laboratory, Faculty of Agriculture, Kyushu University, Fukuoka (Ser. 3, No. 132). 
ringed, strut short and wide, parameres well developed.

The tarsi are characteristic of this subfamily, those of which are threesegmented and claw segments are wanting. The other characters are, however, similar to some genera of the tribe Endaeini of the subfamily Tychiinae (sensu Morimoto, 1962), especially to Sphinxus Roelofs, and the phylogenetic position will be discussed in the revision of the Tychiinae and the related subfamilies, which will appear in this series.

\section{Anoplus Schoenherr}

Schoenherr, 1926, Curc. Disp. Meth.: 244; Schoenherr, 1836, Gen. Sp. Curc., III, 2: 465;

Thomson, 1865, Skand. Col., VII: 319; Reitter, 1916, Fauna Germanica, V: 127; Hoffmann, 1953, Faune de France, 59, Curc. 2: 707.

Type-species : Rhynchaenus plantaris Gyll., by original designation.

\section{Anoplus japonicus sp. nov.}

Black, scape and first segment of funicle reddish brown; derm with sparse fine setae, which are plumose and whitish at lateral margins of thorax.

Head with sparse punctures, interstices as wide as the diameter; forehead between eyes half as wide as the base of rostrum, with a small median
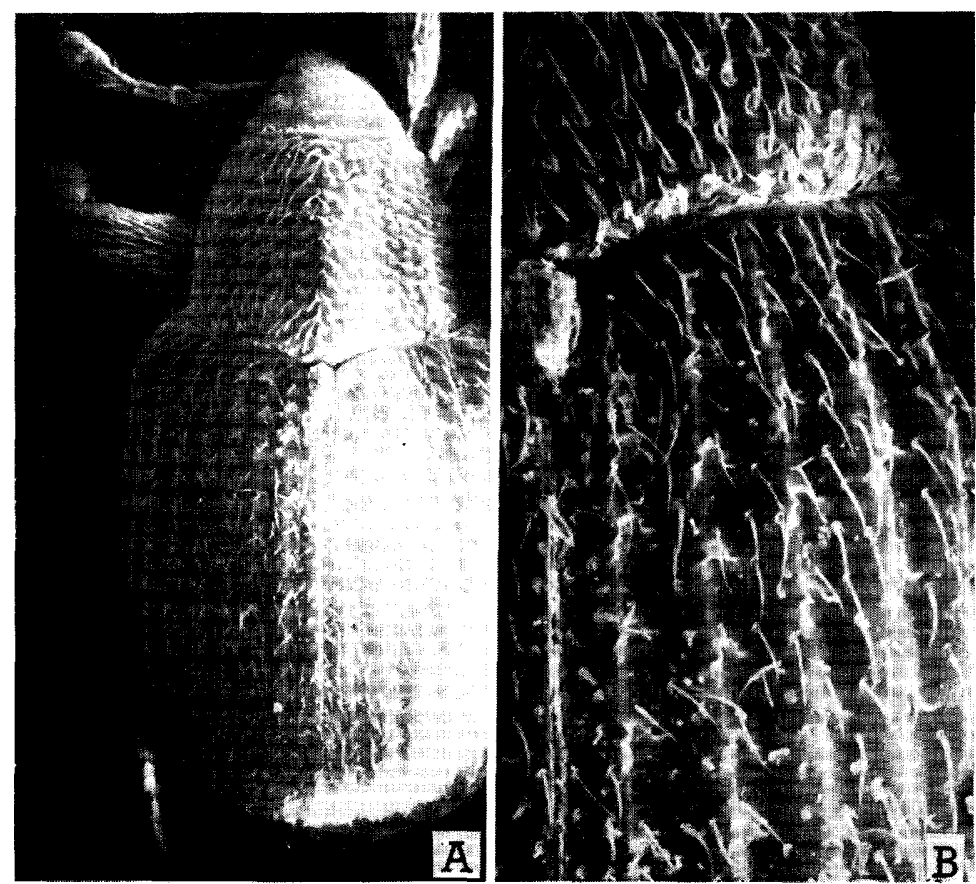

Fig. 1. Anoplus japonicus sp. nov. A: Male, dorsal. B: Part of pronotum and elytra, enlarged. 

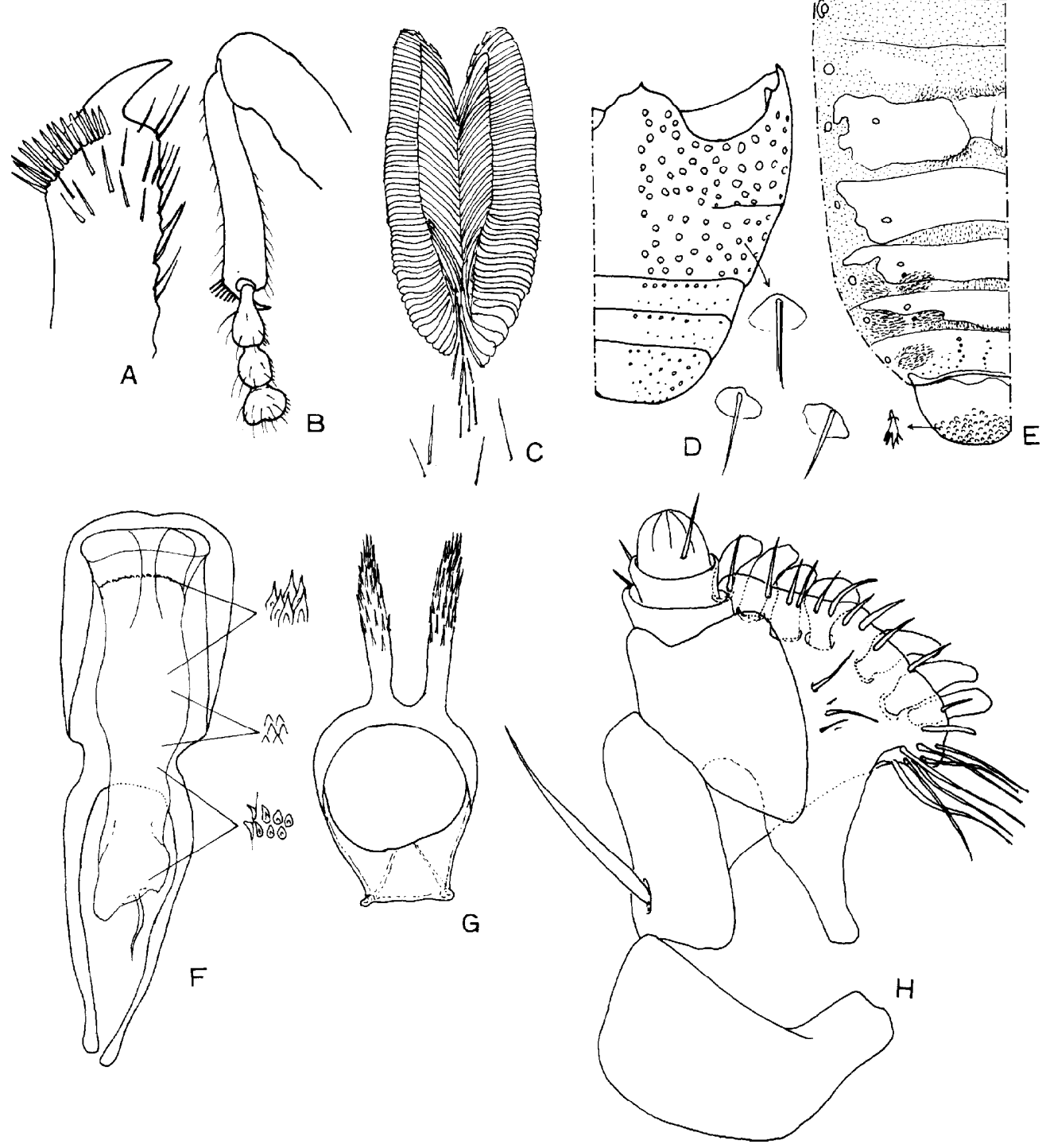

Fig. 2. Anoplus japonicus sp. nov., male. A: Apex of fore tibia. B: Hind leg. C: Part of proventriculus. D: Abdominal sternites. E: Abdominal tergites. F : Penis, dorsal. G: Tegmen and parameres. H: Maxilla.

fovea; rostrum slightly widening from the base to apical third, then slightly tapering distally, evenly and weakly curved, with an ill-defined median impunctate carina on basal half and a short longitudinal median depression between antennal sockets; antennae with scape clavate, first segment of funicle large, 1.2 times as long as wide, second $2 / 3$ times as long as first and 1.2 times as long as wide, third 0.6 times as long as third, third to seventh 


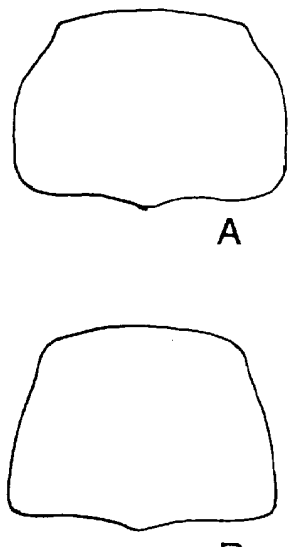

B

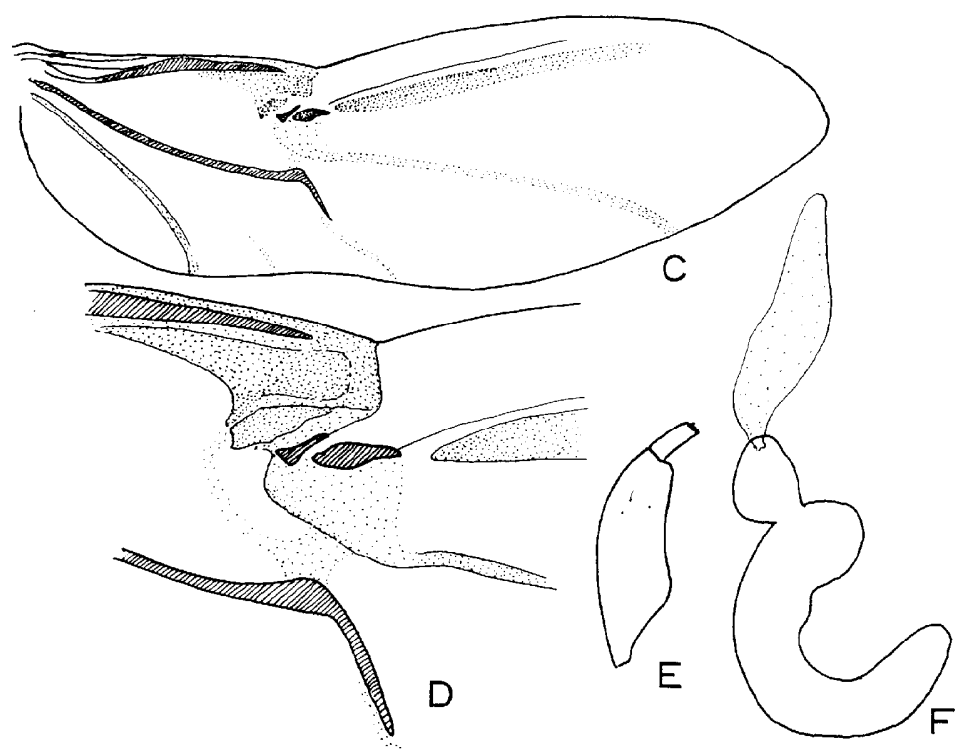

Fig. 3. A: Prothorax of Anoplus plantaris. B: Ditto, Anoplus japonicus Sp. nov. C-F : Parts of Anoplus plantaris. C: Hind wing. D: Ditto, median part, enlarged. E: Ovipositor. F : Spermatheca.

successively slightly broader, club compact, as long as first to fourth segments of funicle combined.

Prothorax 1.4 times as wide as long, widest at the base, straightly and slightly narrowing anteriorly to the middle, then weakly rounded and tapering apically, apex as wide as the length; disk with setiferous punctures. Scutellum oval, with plumose whitish hairs.

Elytra 1.3 times as long as wide, widest at apical third; striae as wide as intervals basally, but becoming a little narrower distally, intervals with a row of small granules.

First and second ventrites punctate, suture between them present on sides, third and fourth ventrites with sparse punctures.

Male. First ventrite flat or very slightly depressed at middle.

Female. First ventrite weakly convex.

Length : 1.6-I. $9 \mathrm{~mm}$ (excl. rostrum).

ноготуре male (Type No. 2421, Kyushu Univ.), Mt. Hakusan, Ishikawa Pref., 31. vii. 1956, Y. Murakami leg.

PARATyPES: Same data as holotype, one male. Same locality as holotype, two females, 6. viii. 1953, Y. Murakami leg.

Distribution : Japan (Honshu : Mt. Hakusan).

\section{Anoplus plantaris (Naezen)}



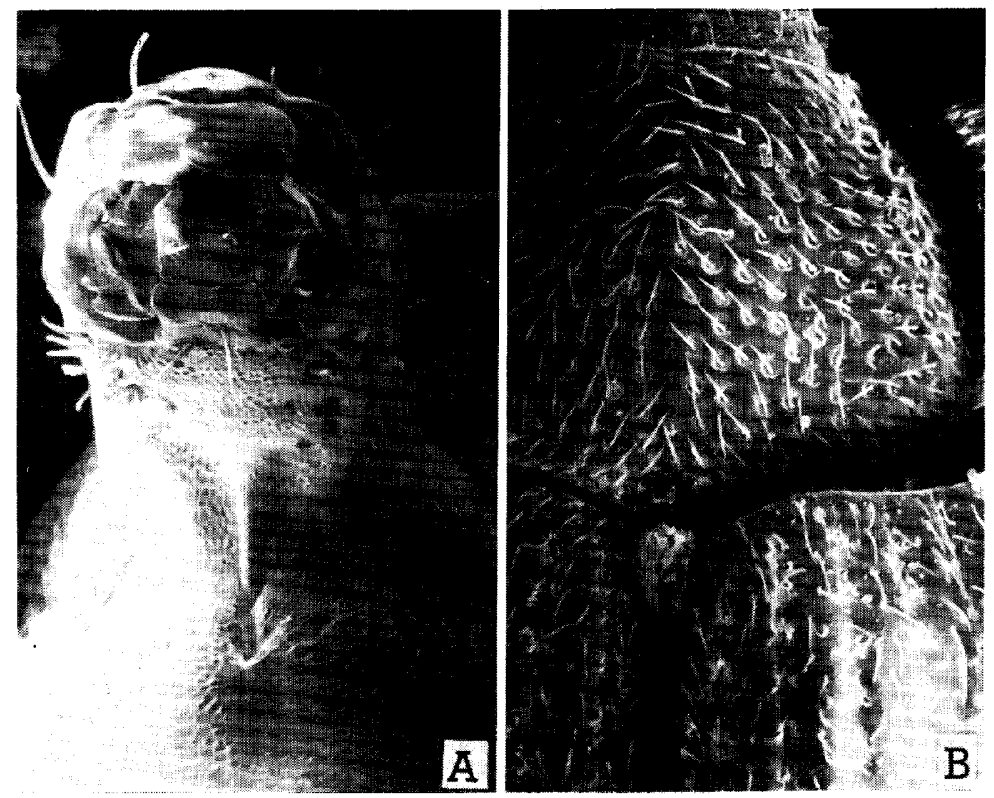

Fig. 4. Anoplus plantaris (Naezen). A: Mouth part, ventral. B : Part of pronotum and elytra, enlarged.

Rhynchaenus plantaris: Gyllenhal, 1813, Ins. Suec., I, 3: 319.

Anoplus plantaris: Gyllenhal, 1836, Gen. Sp. Curc., III, 2: 465.

Anoplus sugiharai Kôno, 1935, Ins. Mats., X: 61. (Is. Shikotan) ; Morimoto, 1962, Sci. Bull. Fac. Agr. Kyushu Univ., 19: 185. (Hokkaido, Kuril Is.). Syn. nov.

Very close to japonicus sp. nov., but separable from it by the following points :

Prothorax 1.5 times as wide as long, almost parallel-sided on basal half, then rather strongly rounded at apical third; disc with punctures a little larger.

Length : 1.9-Z. $0 \mathrm{~mm}$ (excl. rostrum).

Specimens examined : Mt. Rausu, Hokkaido, one female, 1. viii. 1974, I. Matoba leg. Nibushi, Akan Nat. Park, Hokkaido, two exs., 17. vii. 1955, S. Kimoto and 4. vi. 1957, M. Takahashi leg. Ashoro, Hokkaido, three exs., 27. v. 1957, M. Takahashi, 4. vii. 1958, and 2. viii. 1962, S. Kimoto leg. Aizankei, Mt. Daisetsu, Hokkaido, four exs., 29. vii-2. viii. 1955, S. Kimoto and K. Morimoto leg. Yukomanbetsu, Mt. Daisetsu, Hokkaido, two exs., 24-25. vii. 1955, K. Morimoto leg. Nikko, Tochigi Pref., one male, 14. vii. 1956, S. Kimoto. Germany, two exs. Netherlands, two exs.

Distribution : Europe to Amur, Sakhalin, Kamchatka, Kuril Isls. Japan (Hokkaido, Honshu).

Brology: The adults occur on Betula platyphylla var. japonica in Hokkaido. 
The larvae mine in the leaves of Populus nigra, Betula pubescens, B. verrucosa, and Alnus glutinosa in Europe (Hoffmann, 1954; Scherf, 1964).

\section{References}

Egorov, A. 1977. A short review of weevils (Coleoptera, Curculionidae) of Amur region and Khabarovsk Province. in: Skariato, A. O., 0. L. Kryzhnovskii, and A. K. Galkin. (eds.) : Systematics and faunistics of Insects: 7-41 (Academiya Nauka SSSR). (In Russian)

Korotyaev, B. A. 1976. Review of weevils (Coleoptera, Curculionidae) of the Kamchatka Peninsula. Trud.Zool. Inst., 70: 43-5'2. (In Russian)

Kribolutskaya, L. O., M. E. Ter-Minassian, and A. B. Egorov 1978. Curculionid fauna of the Kuril Islands and Saghalin. New Materials on Insects from Saghalin and the Kuril Isls. Trudy Biologo-Potschvenno Instituta, (n. s.) 50: 85-101. (In Russian)

Hoffmann, A. 1954. Faune de France, 59, Coléoptères Curculionides (2e): 487-1208.

Kôno, H. 1935. Die Curculioniden aus den Kurilen II. Ins. Mats., 10: 52-63.

Morimoto, K. 1962. Provisional check list of the family Curculionidae of Japan. I. Sci. Bull. Fac. Agr., Kyushu Univ., 19: 183-217.

- 1962. Key to families, subfamilies, tribes and genera of the superfamily Curculionoidea of Japan excluding Scolytidae, Platypodidae and Cossoninae. J. Fac. Agr., Kyushu U niv., 12: 21-66.

Reitter, E. 1916. Fauna Germanica, Käfer, V. 343 pp.

Schenkling, S. and G. A. K. Marashall 1939. Coleopterorum Catalogus, 168, Curculionidae Addenda, 14 pp.

Scherf, H. 1964. Die Entwicklungsstudien der mitteleuropäischen Curculioniden (Morphologie, Bionomie, Ökologie).Abh.senckenb.naturf. Ges., 506: 1-335. 